\title{
Rethinking Diplomacy and Islam
}

\author{
Ahmad Kazemi-Moussavi*
}

The evolving interaction between Islam and politics has brought to fore the necessity of rethinking the nature and goals of diplomacy in Islam. Here, I will examine the nature of democracy, its history in Islam, and its present situation in the Muslim community in general. Diplomacy in its initial context refers to the process of communication between governments through their official agents with the goal of furthering international cooperation. Through time it came to include noncooperative elements such as propaganda, subversion, manipulation, and economic pressure which were viewed as techniques of foreign policy affecting the international system. Diplomacy is still considered as intellectual politics which serves as the best alternative to physical conflict.

The external relations of Muslims, in a broad sense, may historically be studied in two sets: i) intra-community, i.e. mutual relations of Muslim nations within the community of Islam, and ii) trans-community, i.e. reciprocal relations of Muslim countries with non- Muslim nations outside the Islamic community. We know that during the first half of the twentieth century most regional governments of Muslim states became independent and their intra-community relations were embodied in leagues, organisations, and sometimes unions that are still used to provide a ground for their intra-cultural alliance.

In Islamic tradition, diplomacy was originally imbued with moral values. Historically speaking, the Prophet's way of dealing with the neighbouring towns of Hejaz and Najd and his dispatching envoys and emissaries to Persia, Egypt, Byzantium, and Ethiopia set precedents for future Muslim diplomatic relations. Indeed such diplomatic intercourse was initiated by the Prophet to serve religious purposes. Over time, however, it came to serve political and military purposes as well.

In Islamic literature, external relations have been named siyar which is the plural of sayr, meaning 'travel.' This term was adopted and coined by Muslim scholars of the late eight century, particularly by Muhammad b. al-Hasan al-Shaybānī (d. 805). Due to the expansionist policy of the Umayyad and early Abbasid periods, this genre of siyar and also kharāj (land tribute) writings fostered the idea of unconditional religious war as it sometimes appeared in the titles of some respective books of the time, such as al-Siyar fi ard al-harb. This kind of unilateral characterisation has attached a strong military dimension to the foreign relations of Muslims to the extent that some authors assumed that there was no reciprocity and mutual consent in Islamic foreign policy. ${ }^{1}$

* Ahmad Kazemi-Moussavi is currently Professor of Islamic law and Persian language in the University of Maryland, United States. 
The above mentioned dimension (military), nevertheless, is absent from the several sets of pacts and documents made by the Prophet who entered into peaceful arrangements with his neighbouring communities. They include the 'Charter of Medina', the Treaty of al-Hudaybiyyah and the Letters of the Prophet Muhammad, all of which communicate in a diplomatic manner with various groups - even with antagonist adversaries. We know that there exist a dozen qur'ānic verses and ahäàith which legitimised jihād in the sense of waging war. Nevertheless, most of these verses are qualified (mashrüt), and according to Islamic legal methodology (ușūl al-fiqh) can be either particularised or outweighed by the subsequent contrary verses.

We know that the Prophet himself has been described by the Qur'ān as 'having the best quality' (innak ${ }^{a}$ la- 'alā khuluqin 'ażīm ${ }^{i n}$ ) (68:4). The Muslim community, too, is described by the Qur'ān as uswat has hanat ${ }^{u n}$ meaning the 'best example' (60:4). These two adjectives seem good enough to serve as moral sides to an Islamic diplomacy. Another qur'ānic verse that recognises diversity and communal understanding reads as follows: "We made tribes and nations in order to know each other, and the most pious among you is the dearest before God" (49:13). Finally, the most diplomatically oriented qur'ānic verse orders Muslims to "Invite [all] to the way of the Lord with wisdom and beautiful preaching; and argue with them in ways that are best" (16:125). Three elements are mentioned in this verse which can set patterns for Muslims as representatives of Islamic culture. The first element is hikmah (wisdom) the intellectual insight which produces sound judgment. The second one is 'beautiful preaching' (al-maw' izah al-hasanah) which should affect the audience. The third is the 'best argument' (wa-jädilhum bi-'llatì hiya ahssan) which may convince the adversaries. Some Muslim interpreters likened these categories to that of formal logic, respectively as demonstration (burhān), rhetoric (khițäbah) and disputation (jadal). ${ }^{2}$

The above qur'ānic verses could provide a Muslim community with a criterion of good diplomacy, but presently we observe that some Muslim political leaders (such as Ayatollah Khumaynī, d. 1989) had preferred jihadist verses or at least the following verse: ashidd $\bar{a}^{\prime}$ ' 'ala 'l-kuffăr ${ }^{i}$ wa-ruham $\bar{a}$ 'u baynahum, "compassionate among themselves and strong against the infidels" (48:29).

Here, we have cases of conflict of laws in which experts of Islamic legal methodology (ușül al-fiqh) should determine the most suitable law to be applied in each case. For a Muslim society, the promotion of Islam and its essential values comes first, and in practice the principles of awlawiyyah (priority), mașlahah (consideration of public interest) and the theory of maqāșid (consideration of high objectives of the law) should help scholars to not allow some provisional or de facto expressions of the Qur'ān and the Prophet to dominate the total spirit and fundamentals of Islam. That is to say, the general criterion of Islamic diplomacy should be al-uswah alhasanah and 'the best of human conduct.' We know that the missionary conduct of 
Sufis and Muslim traders in Southeast Asia and West Africa had the greatest impact in terms of the Islamisation of those two regions. In fact, non-governmental Muslim missionary activities appear to be more helpful in promoting Islamic values than the war-regulating writings of scholars such as al-Shaybān̄.

We said that the strong position taken by al-Shaybāni is mainly due to the expansionist policy of the Abbasid caliph of the time that reshaped Islamic foreign relations based on the two important formulas of kharäj and siyar. Indeed, several Medinese verses of the Qur'ān on the necessity of jihäd with unbelievers were held as the central pivot around which the whole idea of foreign relations revolved. Two and half centuries after al-Shaybānī, however, al-Māwardī (d. 1058), author of the first work on Islamic governmental law (al-Ahkām al-sulțāniyyah), did not speak on Islamic foreign relations with the same language that al-Shaybānī did. Al-Māwardī did not concern himself with jihād, rather he devoted a chapter on imārāt al-istilä' which practically legitimises the recognition of a prevailing military government as long as it confesses Islam. Al-Māwardī's position was later polished and reformed by authors such as al-Juwaynī (d. 1085), Abū Ḥāmid al-Ghazālī (d. 111), Ibn Jamā'ah (d. 1333) and others.

The conclusion I may draw from the aforesaid different positions is that Muslim communities of each given period reacted to the circumstances of their time. They did not practically understand the Qur'ān and the Sunnah as presenting a set of fixed and ever-closed ideological principles, except for the idea of promoting the very foundations of the Islamic faith. A law must be predicated on stability and permanence, but its application and interpretation are not so. We may have a different application of the same law, pending on the circumstances of time.

Since the onset of the twentieth century, Muslim communities adopted three major courses which have their origins in the Western experiences of world politics and diplomacy. First the very idea of Nation-State followed by strong nationalism amongst Muslims. Second the principles of human rights articulated in the Cairo Declaration of Islamic Human Rights in 1990. Third the emergence of a number of Muslim organisations such as OIC (1970) and Arab League (1945) etc., that were to provide a wider ground for collective diplomacy. The Organisation of Islamic Cooperation (OIC) is actually the second largest inter-governmental organisation after the United Nations which has membership of currently 57 states. However, in practice these organisations seem to have been engaged in their internal differences more than in coming up with a uniform diplomatic tactic for solving their social and economic problems. These problems include health, education, human security and the problem of authoritarian abuse by state elites over their own citizens. 


\section{Conclusions and Recommendations}

In the modern era, Muslim diplomatic relations adopted two significant courses: i) that religious doctrines should be separated from that of the state's external relations, and ii) that an 'Islamic ideology' must be employed in the state's policy, including the diplomatic relations to provide an added legitimacy for the ruling elite. The first course was the policy of most nascent Muslim nations before the 1970s and is still held up by countries such as Turkey, Malaysia, and Indonesia.

The problem, however, arises with the second course which employs Islam as an ideology to reinforce the foreign policy of a given state. We know that religions (particularly Islam) are not just ideologies or 'belief systems'; rather they are accompanied with sets of rituals and symbolism which require sacred performances. Thus, any kind of criticism or political disagreement would involve a degree of unbearable desecration which might end up turning to an abortive foreign policy and lack of diplomacy. Examples for the second course include several regimes, organisations, and trends of the Middle East among which I put emphasis here briefly on Iran.

Iranian diplomacy or foreign relations is described as 'ideologised foreign policy' according to the Iranian Constitution of 1980, which explicitly legalised the 'exportation of revolution' to other countries. In the conventional approach, usually ideas such as 'reciprocal economic interest' and 'prosperity of nations' set the main goals of the foreign policy of two nations. However, in a dogmatic approach, the ideology comes first which sometimes necessitates military actions, for which we may trace its roots to our historical experiences. Strangely, the politicisation of Islam in the late twentieth century owes its roots partly to the influence of socialist ideas. For example, we may see how the two qur'ānic terms of al-mustad'afün (the disinherited ones) and al-mustakbirün (the arrogant ones) were abused during the Iranian revolution of 1979 as they were incorrectly applied to 'proletarians' and 'capitalists' in order to satisfy political purposes of time.

The last point I wish to make is that Muslims should not allow a politicised ideology to set our principles of diplomacy. Our main goal must be to promote Islamic values through our sincere struggle, sound judgment and good conduct (uswah hasanah). Since we should think as representatives of God on earth, we may feel authorised to decide how to ensure our harmonious relations with other nations and communities according to the totality of the qur'ānic spirit.

\section{Notes}

1. Majid Khadduri, Islamic Law of Nations: Shaybānī's Siyar (Baltimore: Johns Hopkins Press, 1966), 4-7.

2. Sayyid Muhammad Ḥusayn al-Ṭabāṭabā'̄̄, al-Mīzān fí tafsīr al-qur'ān (Qum, Iran: Jamā'at alMudarrisīn fî 'l-Ḥawzah al- 'Ilmiyyah, 1989), 12:371-74. 